\title{
Nocardial cerebral miliary due to massive inoculation
}

Arnaud Lazard, MD, François Lechanoine, MD, and Emmanuel De Schlichting, MD

Neurology ${ }^{\circledR}$ 2020;95:789-790. doi:10.1212/WNL.0000000000010833

Figure Initial and follow-up brain MRI

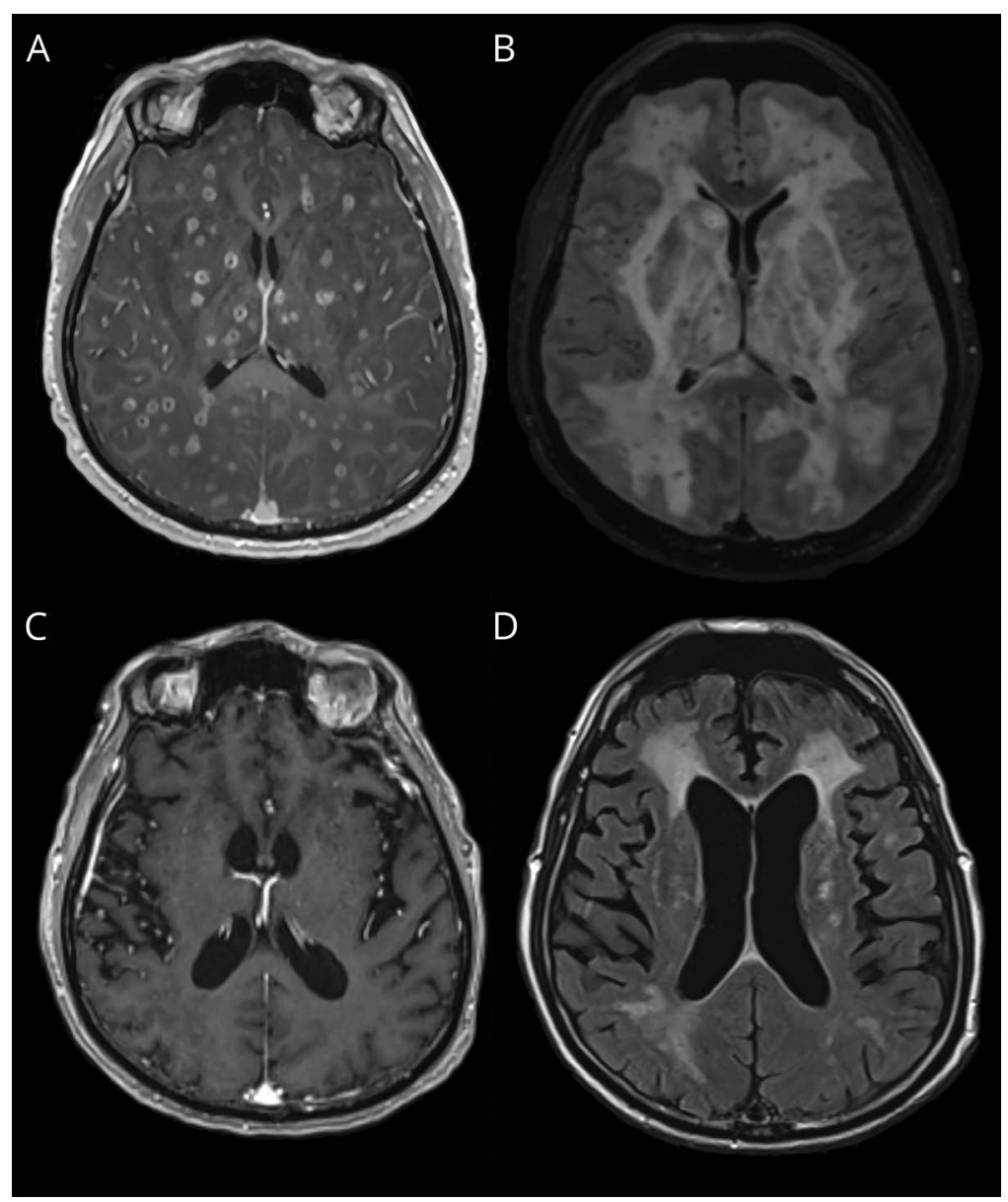

Brain MRI reveals innumerable lesions in axial gadolinium-enhanced T1 (A) associated with extensive edema on coronal fluid-attenuated inversion recovery (B). (C, D) Favorable follow-up at 6 months, with almost complete regression of all lesions and resolution of the edema.

A 68-year-old immunocompetent farmer had persistent pneumonia after scrubbing an antique water tank. He was referred in a febrile coma with supple neck. Brain MRI (figure) showed innumerable enhancing lesions with severe edema. CSF was moderately inflammatory (23 white cells $/ \mathrm{mL}$, proteins $1.2 \mathrm{mg} / \mathrm{mL}$, normal glucose) but excluded bacterial meningitis. Bronchoalveolar lavage and blood cultures were negative.

\section{Correspondence}

Dr. Lazard

alazard@chu-grenoble.fr 
An open brain biopsy revealed abscesses of Nocardia asteroides, a ubiquitous Gram-positive soil pathogen. Treatment consisted of glucocorticoids and complex antibiotics regimen for 6 months. The patient eventually recovered completely. Nocardiosis is rare in immunocompetent patients, and cerebral miliary is an exceptional presentation. ${ }^{1}$

\section{Study finding}

No targeted funding reported.

\section{Disclosure}

The authors report no disclosures relevant to the manuscript. Go to Neurology.org/N for full disclosures.

\section{Appendix Authors}

\begin{tabular}{lll}
\hline Name & Location & Contribution \\
\hline $\begin{array}{l}\text { Arnaud } \\
\text { Lazard, MD }\end{array}$ & $\begin{array}{l}\text { Grenoble University } \\
\text { Hospital }\end{array}$ & $\begin{array}{l}\text { Original idea, drafted } \\
\text { the manuscript }\end{array}$ \\
\hline $\begin{array}{l}\text { François Lechanoine, } \\
\text { MD }\end{array}$ & $\begin{array}{l}\text { Grenoble University } \\
\text { Hospital }\end{array}$ & $\begin{array}{l}\text { Revised the } \\
\text { manuscript }\end{array}$ \\
\hline $\begin{array}{l}\text { Emmanuel De } \\
\text { Schlichting, MD }\end{array}$ & $\begin{array}{l}\text { Grenoble University } \\
\text { Hospital }\end{array}$ & $\begin{array}{l}\text { Edited the figure, } \\
\text { reviewed the } \\
\text { manuscript }\end{array}$ \\
\hline
\end{tabular}

\section{Reference}

1. Ambrosioni J, Lew D, Garbino J. Nocardiosis: updated clinical review and experience at a tertiary center. Infection 2010;38:89-97.

\section{New, Free Mobile Learning App Offers Complimentary Self-assessment CME}

The American Academy of Neurology is pleased to offer a new, mobile educational resource-free to AAN members! The Neurology Question of the Day mobile app offers a quick, convenient, and fun way to assess your knowledge and fulfill selfassessment CME requirements. Get started at AAN.com/QODapp.

\section{Read Capitol Hill Report: Be Informed, Get Engaged}

From the halls of Congress to the offices of regulatory agencies, AAN members and advocacy staff are working tirelessly to represent the needs of you and your patients. Stay up to date with Capitol Hill Report at AAN.com/view/HillReport, or on Twitter at \#AANadvocacy.

\section{Neurology $y^{\circledR}$ Online CME Program}

Earn CME while reading Neurology. This program is available only to online Neurology subscribers. Read the articles marked CME, go to Neurology.org, and click on CME. This will provide all of the information necessary to get started. The American Academy of Neurology (AAN) is accredited by the Accreditation Council for Continuing Medical Education (ACCME) to sponsor continuing medical education for physicians. Neurology is planned and produced in accordance with the ACCME Essentials. For more information, contact AAN Member Services at 800-879-1960. 


\title{
Neurology
}

\begin{abstract}
Nocardial cerebral miliary due to massive inoculation
Arnaud Lazard, François Lechanoine and Emmanuel De Schlichting

Neurology 2020;95;789-790 Published Online before print September 15, 2020

DOI 10.1212/WNL.0000000000010833
\end{abstract}

This information is current as of September 15, 2020

$\begin{array}{ll}\begin{array}{l}\text { Updated Information \& } \\ \text { Services }\end{array} & \begin{array}{l}\text { including high resolution figures, can be found at: } \\ \text { http://n.neurology.org/content/95/17/789.full }\end{array} \\ \text { References } & \text { This article cites } 1 \text { articles, } 0 \text { of which you can access for free at: } \\ & \text { http://n.neurology.org/content/95/17/789.full\#ref-list-1 } \\ \text { Subspecialty Collections } & \text { This article, along with others on similar topics, appears in the } \\ & \text { following collection(s): } \\ & \text { Abscess } \\ \text { http://n.neurology.org/cgi/collection/abscess } & \text { Bacterial infections } \\ & \text { http://n.neurology.org/cgi/collection/bacterial_infections } \\ & \text { MRI } \\ & \text { http://n.neurology.org/cgi/collection/mri } \\ & \text { Information about reproducing this article in parts (figures,tables) or in } \\ & \text { its entirety can be found online at: } \\ & \text { http://www.neurology.org/about/about_the_journal\#permissions } \\ \text { Permissions \& Licensing } & \text { Information about ordering reprints can be found online: } \\ & \text { http://n.neurology.org/subscribers/advertise }\end{array}$

Neurology ${ }^{\circledR}$ is the official journal of the American Academy of Neurology. Published continuously since 1951, it is now a weekly with 48 issues per year. Copyright @ 2020 American Academy of Neurology. All rights reserved. Print ISSN: 0028-3878. Online ISSN: 1526-632X.

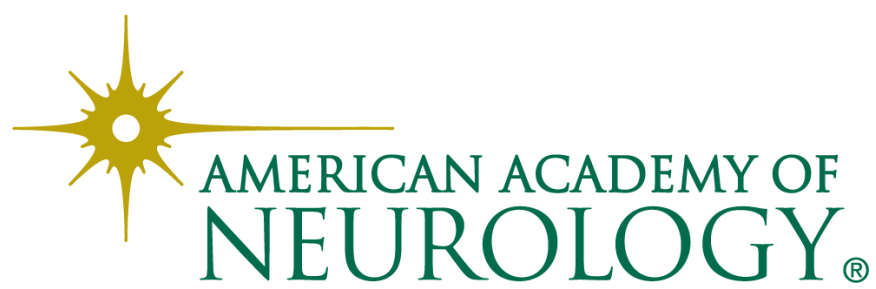

